\title{
Impact of Some Amendments on Some Soil Properties and Plant Growth in Desert Area of Iran
}

\author{
M. K. Kianian ${ }^{*}$, H. R. Asgari², F. Bahadori ${ }^{3}$ \\ ${ }^{1}$ Desert Studies Faculty, Semnan University, Semnan, Iran \\ ${ }^{2}$ Arid Land Management, Faculty of Rangeland and Watershed Management, Gorgan University of \\ Agricultural Sciences and Natural Resources, Gorgan, Iran \\ ${ }^{3}$ Research Division of Natural Resources Department, Semnan Agricultural and Natural Resources Research and Education \\ Center, AREEO, Semnan, Iran \\ Email: ^m_kianian@semnan.ac.ir
}

How to cite this paper: Kianian, M.K., Asgari, H.R. and Bahadori, F. (2018) Impact of Some Amendments on Some Soil Properties and Plant Growth in Desert Area of Iran. Open Journal of Ecology, 8, 339-355.

https://doi.org/10.4236/oje.2018.86021

Received: April 1, 2018

Accepted: June 8, 2018

Published: June 11, 2018

Copyright (C) 2018 by authors and Scientific Research Publishing Inc. This work is licensed under the Creative Commons Attribution International License (CC BY 4.0).

http://creativecommons.org/licenses/by/4.0/

\begin{abstract}
Water availability and soil physicochemical properties are the most important factors for the establishment and growth of plant seedlings in arid and desert areas. Improving water use efficiency and soil properties are two major factors for sustainable development in these regions. Therefore, this research aimed to study the effectiveness of biological hydrogel (b), PLANTBAC vegetation layer (PB), sand (sa) and barley straw (st) with inter-row system on some soil properties, including $\mathrm{N}, \mathrm{Cl}, \mathrm{Zn}, \mathrm{Fe}$, clay, silt and sand percentages, $\rho_{b}$ and water use efficiency under the cultivation of Nitraria schoberi. This experiment was tested in a split plot design with 3 replications and 10 observations in 2015 during 2 years at Semnan province's Natural Resources Research Station. Data analysis was carried out in SAS software version 9.1.3. According to the results, the highest amount of $\mathrm{Cl}$ was obtained at non-micro catchment by straw and sand treatments, as well as at micro catchment by PB treatments. The highest amount of $\mathrm{Zn}$ was obtained at non-micro catchment by straw treatment (1.106). The results of mulch effect on Fe showed that four mulch treatments did not have significant difference with the control. Also, the highest amount of total $\mathrm{N}$ content was observed at micro catchment by hydrogel treatment. There was not any significant difference among environment and clay, silt and sand treatments and about plant establishment and, all four mulch treatments had significantly higher moisture content and establishment than the control. The results of mulch effect on water use efficiency showed that there was a significant difference between all four mulch treatments $(P<0.01)$ and the control. The highest water use efficiency occurred in
\end{abstract}


sand treatment (0.243), and the lowest was under straw mulches (0.154). Thus, considering the effects of different types of mulch on soil properties and considering the price of each, the availability and area conditions, they can be used to establish plants in desert areas, and therefore, restore these areas.

\section{Keywords}

PLANTBAC, Soil Properties, Nitraria schoberi, Establishment, Semnan

\section{Introduction}

One way to use saline soils and water in desert area is to identify and use salt and drought tolerant plants [1] [2] [3] [4] [5]. Another strategy is use of hydrogels. Water retained in hydrogels serves as a soil water reservoir to maximize the uptake of water by plants. In addition, the use of appropriate amending materials can improve chemical, physical and biological properties of soil and reduce soil salinity and other stresses [6]. They also act as an intermediary which influences the antioxidant defense mechanisms [7], and improve unfavorable soil properties and nutrient uptake by increasing macro-aggregates, organic carbon and macro-nutrient status [8]. Mulch protects soil from water erosion by reducing the impact of rain drops. Partial residuals of mulch in soil can strongly affect dynamics and amount of runoff [9].

Blavet et al. [10], reported a significant reduction of soil loss when plant debris was retained on the soil surface. Higher amounts of residuals on soil surface have positive effects on soil erosion control, organic matter content and physical, chemical and biological properties. The effect of plant residues on soil organic matter content is strictly related to the amount of organic matter and slightly to type of materials [11]. Straw and other mulches are temporary solutions for poor soils [12]. Straw mulch reduces runoff, increases infiltration, moderates soil surface temperature and reduces evaporation [13] [14] [15]. In developing countries, gravel or sand is usually preferred because of their low cost and availability. Gravel effectively reduces evaporation and runoff, improves infiltration, moderates soil temperature and retains soil fertility [16]. It can also indirectly improve crop yield via the interaction between increased soil water and moderated soil temperature.

Hongyong Sun [17], investigated the determination of water use and storage potential with three types of mulch, which showed that straw mulch had lower water consumption and water storage capacity than two other mulches. Zhao et al. [18], examined the effect of straw mulch on soil moisture and salinity. The results showed that in mulch plots, salinity decreased and soil moisture content increased compared to non-mulch plots. Kaltenleithner et al. [19], investigated the effect of gravels on soil water content in northern Ethiopian heights. The results showed an increase in soil water content. Yang et al. [20], concluded that a 
super adsorbent polymer with good properties of water conservation was very effective for plant growth.

In case of using super-absorbents materials, little work has been done for seedlings establishment. Related to rainwater harvesting, different methods are exercised in arid areas to compensate water scarcity [21] [22] [23]. It is possible to use rain water harvesting techniques along with absorbent materials and amendments, related to the condition of the area in micro and even macro scales. These measures can to some extent guarantee the success of seedlings establishment and water use efficiency [24]. As previously stated and regarding the rich background of applying oil mulches in Iran and elsewhere, some adverse environmental properties might be conceived for oil mulches. They also require expensive transportation costs, and hence could be replaced with new and more compatible materials [25]. Therefore, this research takes a closer look at the effectiveness of biological hydrogels (biological mulch or b), PLANTBAC vegetation layer (pb), sand (sa) and barley straw (st) along with rain water harvesting techniques in micro-catchment scale (inter-row system) on some of soil chemical and physical properties such as nitrogen $(\mathrm{N})$, chloride $(\mathrm{Cl})$, zinc $(\mathrm{Zn})$ and iron $(\mathrm{Fe})$, clay, silt and sand percent, bulk density and water use efficiency under cultivation of Nitraria schoberi.

\section{Materials and Methods}

\subsection{Study Area}

The study was carried out during 2 years in 2015 at Semnan Natural Resources Research Station, as a typical desert area (The latitude and longitude of the research area are $53^{\circ} 28^{\prime}$ and $35^{\circ} 35^{\prime}$ northeast), with an average precipitation of $109.3 \mathrm{~mm}$ that most of which falls in winter. The evaporation rate and sunny hours reaches to as high as $2582.3 \mathrm{~mm}$ and $3134.5 \mathrm{~h}$. Average annual temperature, the minimum relative moisture and annual frosting days is $18^{\circ} \mathrm{C}, 23 \%$ and 19. This area is characterized by an arid and cold climate based on the de Marton method (meteorology organization of Semnan province).

\subsection{Research Methodology}

First in June 2015, the seeds of Nitraria schoberi were planted in plastic pots (pots were with $10 \mathrm{~cm}$ diameter and $10 \mathrm{~cm}$ height, and their texture was sandy clam loam) in the nursery of Hasanabad station located in Damghan city and then transferred to Semnan research station. After that, seedlings were planted in field as a split plot design with a randomized complete block base with 3 replications and 10 observations in December 2015. The first irrigation was performed immediately after planting seedlings. The treatments were as bellows.

Rain water harvesting technique at two levels (technique application or inter-row systems and non-technique application). The height of the ridges is 40 to 100 centimeters and their distance is 2 to 10 meters. technique application 
means using the rain water harvesting (inter-row systems) and non-technique application means not using the rain water harvesting (inter-row systems). Inter-row systems are triangular cross-sectional ridge or embankments that are made along the main slope of the earth. Ridge can be compressed or covered with insulating or waterproofing materials, to increase the runoff coefficient. Runoff from ridges is stored among them.

Mulch and moisture absorbent materials were at five levels (biological hydrogel or biological mulch), PLANTBAC, sand, straw, and control treatment). PLANTBAC treatment is made by Plantbacter company in Germany (http://www.plantbacter.com/). Its properties are as bellows: "Dimensions: 80 $\mathrm{cm} \times 60 \mathrm{~cm} \times 2 \mathrm{~cm}$; Weight: $1.8 \mathrm{~kg}$; Water absorption capability: $10 \mathrm{l} / \mathrm{m}^{2}$; Erosion resistance: 5 - 8 years". First halve a full piece and then place the two halved pieces first at the bottom of the pit and then above it at a distance of $20 \mathrm{~cm}$. Finally, put the seedlings and the soil around it. For biological hydrogel that was made by Polymer Research Institute of Iran, first added 140 liters of water in a barrel of 220 liters and heat to 80 degrees centigrade. Then, added 40 liters of concentrated hydrogel to dilute it. Then, 2 liters were placed in the soil under the plant and 1 liter in soil around the seedling. For sand treatment, sand with $5 \mathrm{~cm}$ thick (sand grain with 2 to $5 \mathrm{~mm}$ in diameter), was placed in the plant shader section. For straw treatments, did the same. Time of doing above treatment was in December 2015.

Sampling was as 3 samples at each repetition and with 5 treatments that it comes to 15 samples in general. Amount of each sample was 2 kilogarms. Time of first sampling (depth of sampling was 0 to $30 \mathrm{~cm}$ ) was before adding materials (mulches and hydrogels) and after first irrigation (until it reaches at RAW level) in October 2015 and second time was after two years in July 2017 during plant flowering. Then, soil and plant samples were transferred to the laboratory for further analysis. Iron and zinc were measured by atomic absorption device model Buck210Vgp, nitrogen by Kjeldahl device model V40, chlorine by Mohr method (silver nitrate), soil texture by Baykas hydrometer method, bulk density by paraffin and clod method [26]. and water use efficiency based on the ratio between the yield and the consumed water (the volume of water for irrigation of all treatments was based on moisture reaching to the RAW (allowable drainage level) in control plant (without mulch) and the amount of water required to reach the field capacity level in the control plant (15 liters per seedling), Which was calibrated by TDR device. About the establishment percent, the established plants in each treatment and repetition were counted. Finally, considering the volume of consumed water for all treatments and biomass obtained in each treatment, water use efficiency (WUE) and also the efficiency of the techniques was determined.

Data normality for each property was tested by Shapiro-Wilk, Kolmogorov-Smirnov, Cramér-von Mises and Anderson-Darling tests (Table 1). Data analysis was carried out as split plot in a randomized complete blocks design with three 
replications. The environmental factor with two levels (non-micro-catchment and micro-catchment) and mulch application with five levels (control group, PLANTBAC, bio-hydrogel, straw, and sand) were included in data analysis as independent variables. The analysis was performed using SAS software version 9.1.3. The mean comparison of was performed using the LSD test. Moreover, the correlation between different factors was evaluated using the Pearson correlation coefficient, and the results are provided in details as bellows.

\section{Results and Discussion}

The results of soil properties analysis (nitrogen, chloride, zinc and iron, clay, silt and sand percent, bulk density and water use efficiency) are provided in Table 1 and Table 2. Since this is the first time that the bio-hydrogel and PLANTBAC treatments have been used for this purpose, we were unable to compare with other research articles, However, there are some cases for application of sand and straw mulches. Data normality for $\mathrm{Cl}^{-}$was confirmed by all four methods. The results of variance analysis showed that the effects of mulch and mulch $\times$ environment are significant $(P<0.01)$ (Table 1). The highest amount of $\mathrm{Cl}^{-}$for non-micro-catchment environment was for straw (26.1) and sand (24.733) and for micro-catchment environment was for PLANTBAC treatments (27.344) (Table 2). Also in the non-micro-catchment environment, $\mathrm{Cl}^{-}$level in sand and straw treatments were significantly higher than the control (21.711). Two treatments of PLANTBAC (27.344) and straw (25.256) had higher $\mathrm{Cl}^{-}$compared to the control (19.578) at the micro-catchment environment (Figure 1(a)). At two environments (micro-catchment, and non-micro-catchment), B treatment had lowest amount respectively.

Pearson correlation analysis between soil $\mathrm{Cl}^{-}$and other properties showed that chloride has moderate negative correlation with magnesium (-0.525) and moderate positive correlation with the soil phosphorus (0.535). According to Yong et al. [27] concluded that hydrophilic polymers contribute to Populus popularis

Table 1. Analysis of variance of experimental factors.

\begin{tabular}{|c|c|c|c|c|c|c|c|c|c|c|}
\hline \multirow{2}{*}{$\begin{array}{l}\text { Sources of } \\
\text { Changes }\end{array}$} & \multirow{2}{*}{$\begin{array}{l}\text { Degree of } \\
\text { freedom }\end{array}$} & \multicolumn{9}{|c|}{ Squares mean } \\
\hline & & $\mathrm{Cl}$ & $\mathrm{Zn}$ & $\mathrm{Fe}$ & Clay & Silt & Sand & $\mathrm{N}$ & $p_{\mathrm{b}}$ & WUE \\
\hline Block & 2 & $0.459 \mathrm{~ns}$ & $0.026 \mathrm{~ns}$ & $0.01 \mathrm{~ns}$ & $0.797 \mathrm{~ns}$ & $1.199 \mathrm{~ns}$ & $109.608 \mathrm{~ns}$ & $0.00006 \mathrm{~ns}$ & $0.0016 \mathrm{~ns}$ & $0.002009 \mathrm{~ns}$ \\
\hline Environment & 1 & $1.096 \mathrm{~ns}$ & $0.448^{*}$ & $0.356 \mathrm{~ns}$ & $0.14 \mathrm{~ns}$ & $27.17 \mathrm{~ns}$ & $185.82 \mathrm{~ns}$ & $0.00075 \mathrm{~ns}$ & $0.0002 \mathrm{~ns}$ & $0.00308 \mathrm{~ns}$ \\
\hline The first error & 2 & 4.476 & 0.006 & 0.054 & 3.239 & 5.96 & 6.549 & 0.00009 & 0.0019 & 0.003917 \\
\hline Mulch & 4 & $54.355^{\star *}$ & $0.051^{\star *}$ & $0.105^{\star}$ & $1.421 \mathrm{~ns}$ & $3.974 \mathrm{~ns}$ & $6.44 \mathrm{~ns}$ & $0.00118^{\star *}$ & $0.0035^{\star *}$ & $0.012399^{* *}$ \\
\hline Mulch $\times$ Environment & 4 & $33.481^{\star *}$ & $0.042^{*}$ & $0.028 \mathrm{~ns}$ & $0.182 \mathrm{~ns}$ & $5.999 \mathrm{~ns}$ & $6.969 \mathrm{~ns}$ & $0.00022^{\star}$ & $0.0009 \mathrm{~ns}$ & $0.000563 \mathrm{~ns}$ \\
\hline Experimental error & 16 & 5.043 & 0.01 & 0.023 & 1.547 & 3.28 & 13.794 & 0.00007 & 0.0004 & 0.000449 \\
\hline CV (\%) & & 10.21 & 14.17 & 12.12 & 6.18 & 12.04 & 5.44 & 23.33 & 1.23 & 11.83 \\
\hline
\end{tabular}

Sign of ${ }^{*}$ and ${ }^{* *}$ show significance at a confidence level of $5 \%$, and $1 \%$, respectively. 
Table 2. Mean comparison of traits.

\begin{tabular}{ccccc}
\hline Environment & Mulch & $\mathrm{Cl}$ & $\mathrm{Zn}$ & $\mathrm{N}$ \\
\hline & $\mathrm{c}$ & $21.711 \mathrm{bc}$ & $0.847 \mathrm{~b}$ & $0.016 \mathrm{e}$ \\
Non-Micro-catchment & $\mathrm{pb}$ & $19.611 \mathrm{~cd}$ & $0.768 \mathrm{bc}$ & $0.041 \mathrm{bc}$ \\
& $\mathrm{b}$ & $18.789 \mathrm{~cd}$ & $0.828 \mathrm{~b}$ & $0.037 \mathrm{bc}$ \\
& $\mathrm{st}$ & $26.1 \mathrm{a}$ & $1.106 \mathrm{a}$ & $0.032 \mathrm{~cd}$ \\
& $\mathrm{sa}$ & $24.733 \mathrm{ab}$ & $0.677 \mathrm{Bcd}$ & $4221.516 \mathrm{de}$ \\
& $\mathrm{c}$ & $19.578 \mathrm{~cd}$ & $0.59 \mathrm{de}$ & $0.021 \mathrm{de}$ \\
Micro-catchment & $\mathrm{pb}$ & $27.344 \mathrm{a}$ & $0.486 \mathrm{e}$ & $0.043 \mathrm{bc}$ \\
& $\mathrm{B}$ & $16.622 \mathrm{~d}$ & $0.0601 \mathrm{cde}$ & $0.066 \mathrm{a}$ \\
& $\mathrm{St}$ & $25.256 \mathrm{ab}$ & $0.642 \mathrm{cde}$ & $0.047 \mathrm{~b}$ \\
& $\mathrm{Sa}$ & $20.233 \mathrm{~cd}$ & $0.683 \mathrm{bcd}$ & $0.021 \mathrm{de}$
\end{tabular}

Means with at least one similar letter are not significantly different with each other.

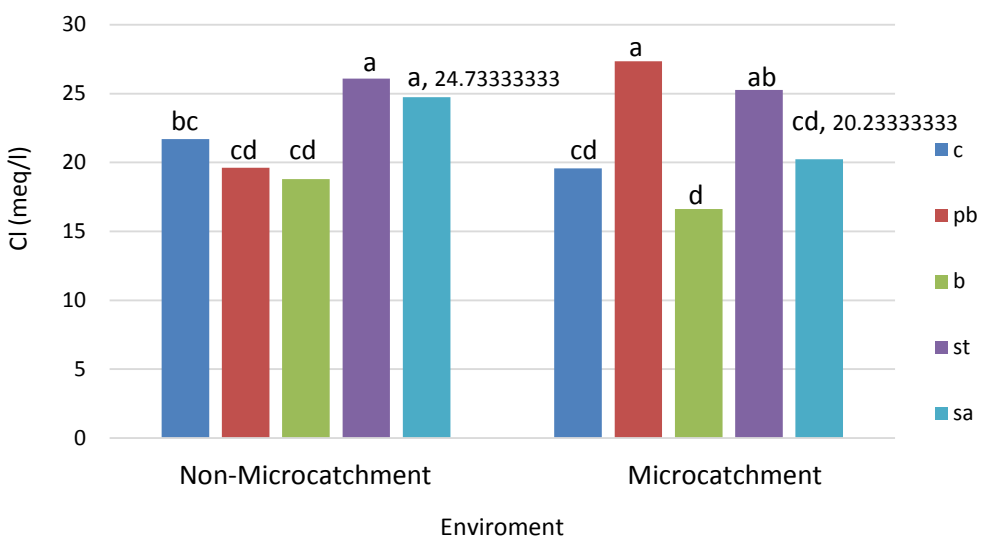

(a)

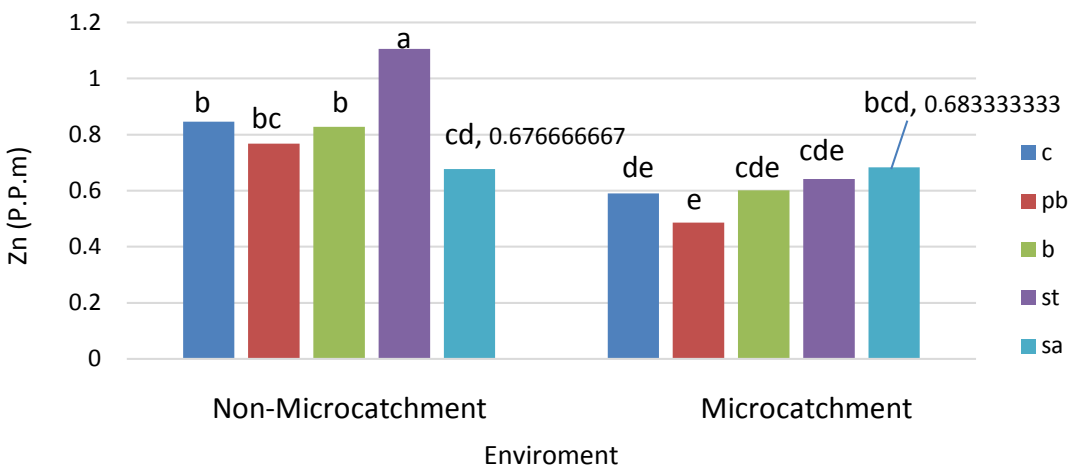

(b)

Figure 1. (a) The effect of different treatments on chloride $\left(\mathrm{Cl}^{-}\right)$; (b) The effect of different treatments on Zinc (Zn). Other symbols mean biological hydrogels (b), PLANTBAC vegetation layer (pb), sand (sa) and barley straw (st).

tolerance according to the following reasons: hydrophilic polymers maintain $\mathrm{Cl}^{-}$ in the soil medium due to their high water holding capacity and restrict exces- 
sive accumulation of toxic ions in plant tissues. The amount of $\mathrm{Cl}^{-}$systematically increased $(p<0.05)$ during the irrigation season in all treatments except for the organic mulch treatment [28].

Data normality for $\mathrm{Zn}$ was confirmed by all four methods. The results showed that the effects of environment, mulch and mulch $\times$ environment were significant $(P<0.05)$ (Table 1$)$. The highest $\mathrm{Zn}$ content was for straw treatment (1.106) and non-micro-catchment environment (Table 2). Also, there was no significant difference in the amount of $\mathrm{Zn}$ between the two bio-hydrogel and PLANTBAC treatments in non-micro-catchment environment. In the meantime, the amount of $\mathrm{Zn}$ in the sand treatment (0.677) was significantly lower than the control (0.847). The lowest level of $\mathrm{Zn}$ was related to B treatment $(0.0601)$ at micro-catchment. There was no significant difference between treatments in micro-catchment environment compared with the control (Figure $1(b))$.

Pearson correlation analysis between $\mathrm{Zn}$ and other properties showed that $\mathrm{Zn}$ has moderate positive correlation with sodium, EC and SAR $(0.477,0.487$, and 0.440 ) and moderate negative correlation with forage ash and leaf dry weight $(-0.417$ and -0.440$)$. Finally, it has a strong negative correlation with DMD (-0.722). Ni et al. [29], showed that sand mulching provides nutrients ( $\mathrm{Zn})$ in the root zone. Since organic mulches decompose under appropriate water and temperature levels, nutrients $(\mathrm{Zn})$ are released to the soil and become available for root uptake or microbial use [30].

Data normality for Fe was confirmed by all four methods. The results showed that the effect of mulch was significant $(P<0.05)$ (Table 1$)$. Mean comparison of mulch effect on Fe showed that all four mulch treatments were not significantly different from the control (Table 2). However, the highest amount of Fe occurred in PLANTBAC treatment with a significant difference from bio-hydrogel, straw and sand treatments (Figure 2(a)). Pearson correlation analyze between Fe in soil and other properties showed a moderate positive correlation with magnesium, electrical conductivity, sand percent, stem organic matters and organic matters of aerials organs $(0.416,0.481,0.487,0.508$ and 0.406$)$; a moderate negative correlation with silt percent and plant dry weight (-0.550 and -0.447). [29] showed that sand mulching provides nutrients $(\mathrm{Fe})$ in the root zone. Since organic mulches decompose under appropriate water and temperature levels, nutrients $(\mathrm{Fe})$ are released into the soil and become available for root uptake or microbial use [30].

Data normality for $\mathrm{N}$ was confirmed by all four methods. The results showed that the effects of mulch and mulch $\times$ environment were significant $(P<0.01)$ (Table 1). The highest total $\mathrm{N}$ occurred in micro-catchment environment and hydrogel treatment (0.066) (Table 2). Also in non-micro-catchment treatment, total $\mathrm{N}$ in hydrogel (0.037), PLANTBAC (0.041) and straw (0.032) treatments was significantly higher than the control (0.016), but total $\mathrm{N}$ in sand treatment did not have any significant difference. Three treatments of PLANTBAC (0.043), 


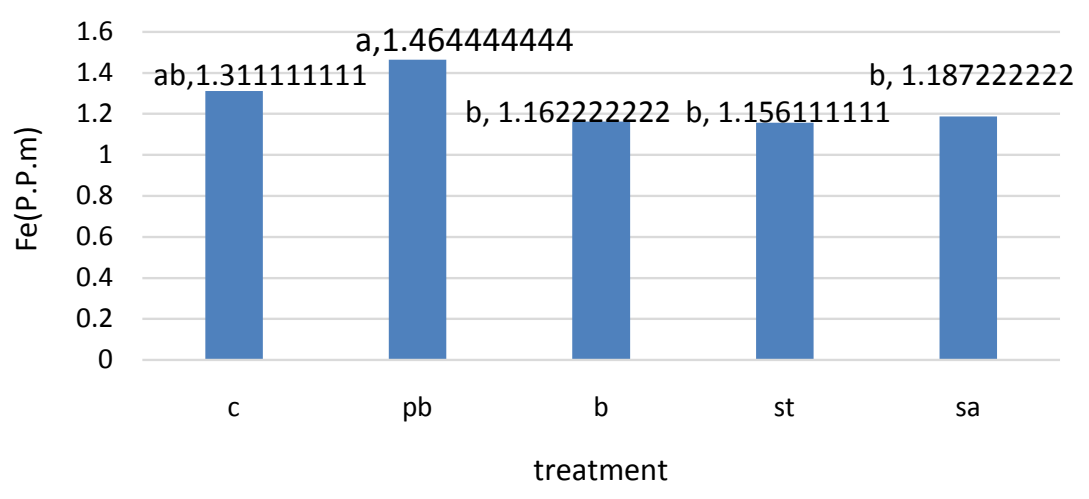

(a)

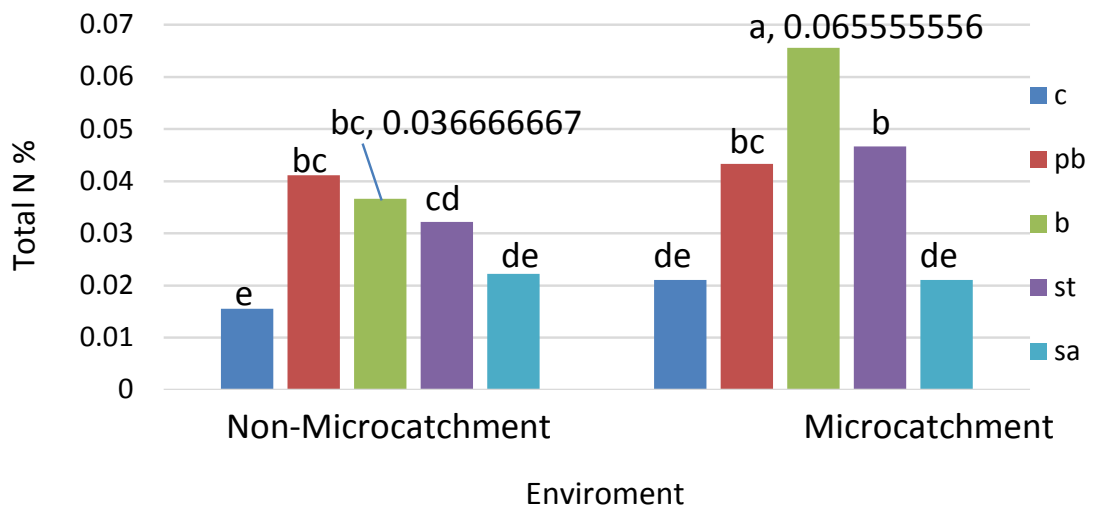

(b)

Figure 2. (a) Effect of different treatments on Fe; (b) Effect of the different treatments and environments on total nitrogen $(\mathrm{N})$. Other symbols mean biological hydrogels (b), PLANTBAC vegetation layer (pb), sand (sa) and barley straw (st).

bio-hydrogel (0.066) and straw (0.047) had significant differences with the control (0.021) in the micro-catchment environment, while total $\mathrm{N}$ in the sand treatment was similar to that in the control (Figure 2(b)).

Pearson correlation analysis between $\mathrm{N}$ and other properties showed a moderate positive correlation with carbon storage of plant, organic materials of leaf and root, DMD, forage ash and urease enzyme (0.431, 0.550, 0.413, 0.478, 0.408 and 0.401 and moderate negative correlation with bulk density and litter organic matter ( -0.578 and -0.410$)$. Finally, total $\mathrm{N}$ showed a strong positive correlation with fresh and dry weight of the root and soil moisture (0.612, 0.652 and 0.705$)$.

The straw mulch did not result in greater soil nitrogen [31]. Although gravel-sand mulch can conserve soil moisture, it may also lead to long-term decrease in total organic $\mathrm{N}$ [32]. In study by $\mathrm{Ni}$ et al. [29], sand mulch did not affect total nitrogen content, but it increased the available nitrogen. Since organic mulches decompose under appropriate water and temperature levels, nutrients $(\mathrm{N})$ are released to the soil and become available for root uptake or microbial use [30]. Gravel mulches always contain fewer nutrients and are difficult for microorganisms to decompose. Thus, increase in SAN (soil available nitrogen) content after RG (round gravel) treatment are due to the fact that gravels provide a suit- 
able condition for the growth of microorganisms that release more nutrients via SOM decomposition. In addition, gravel mulch can trap sediments, which contain nitrogen and organic matter and help to improve soil nutrient status [33]. Plant nutrient uptake could decrease significantly SAN over time. Soil moisture and organic mulch were shown to have a strong indirect influence on the available soil nitrogen [34]. The highest total nitrogen occurred under mulch application with the availability of $100 \%$ of the recommended irrigation, where the condition is very suitable for nitrogen mineralization. Mulching significantly affect the amount of nitrogen in soil. Total $\mathrm{N}$ in surface layer under mulch treatment $(\mathrm{M}+100 \% \mathrm{I})$ was higher than the control treatment (Without-M+100\%I) by 31.0 and $65.9 \%$ in the beginning and end of the season, respectively. These results are similar to those of [35] and [36]. It is argued that nitrogen mineralization capacity is higher at the soil surface and decreases downward. The addition of compost to the soil increases $\mathrm{NH}^{+4}$ level due to ammonification, promoting the growth of the nitrifying bacteria population. This may explain the higher nitrate concentration in mulched plots [37] [38].

Data normality for clay content was confirmed by all four methods. The results showed no significant difference between the treatments $(P<0.05)$ (Table 1). Therefore, we can conclude that there wasn't a significant difference between the environment and the treatments in terms clay. Pearson correlation analysis between the clay with other properties showed that the clay has moderate positive correlation (0.486) with WSC.

Data normality for silt content was confirmed by all four methods. The results showed no significant difference between the treatments $(P<0.05)$ (Table 1$)$. Consequently, it can be concluded that there was no significant difference between the environment and treatments in terms of silt rate $(P<0.05)$. Pearson correlation analysis between silt and other properties showed a moderate positive correlation with dry weight of plants (0.465), a weak positive correlation with NDF (0.395), a moderate negative correlation with Fe and soil electrical conductivity $(-0.550$ and -0.425$)$, and a strong negative correlation with sand $(-0.667)$.

Data normality for sand content was confirmed by all four methods. The results showed no significant difference between the treatments $(P<0.05)$ (Table 1 ). Accordingly, it can be concluded that there was no significant difference between the environments and the treatments in terms of sand. Pearson correlation analysis between sand and other properties showed a moderate positive correlation with $\mathrm{Fe}$ and electrical conductivity (0.487 and 0.557), a moderate negative correlation with NDF, alkaloid, DMD, leaf dry weight and forage ash dry weight $(-0.402,-0.406,-0.439,-0.455,-0.502$ and -0.555$)$, weak negative correlation with moisture $(-0.396)$, and a strong negative correlation with silt content (-0.667). According to Qi et al. [39] in a study entitled "soil properties of the desert after thirty years of plant establishment in province of Shaanxi of Northern China" concluded that plant establishment in desert areas does not al- 
ter soil texture. According to Noy-Meir [40], soil texture and structure affect moisture and influence plant seedlings establishment. This study only examined a two-year-old gravel-sand mulch; however, the assessment of the long-term effects of gravel-sand mulch on soil texture requires further studies [41].

About bulk density, Data normality for bulk density was confirmed by all four methods. The results of the analysis of variance showed that the effect of mulch was significant $(P<0.01)$ (Table 1$)$. The comparison of the average effect of mulch on soil bulk density showed that both PLANTBAC and bio-hydrogel treatments had bulk densities significantly less than the control. The sand and straw were also not significantly different from the control (Figure 3).

Pearson correlation analysis between bulk density with other properties showed a moderate negative correlation with carbon storage and leaf area of plant, dry biomass weight, nitrogen, plant's $C$ storage, root and leaf dry weight $(-0.420,-0.465,-0.537,-0.578,-0.420,-0.501$ and -0.410$)$ and moderate positive correlation with litter organic matter, SAR and soil ADF $(0.418,0.452$ and 0.468 ). The results reported on the effects of mulch on soil bulk density are fairly ambiguous. The effect of mulch on soil bulk density varies with soil properties, climate and management. Ji and Unger [42] showed that organic matter reduces soil bulk density. In contrast, other researchers have observed that mulching either significantly increase soil bulk density [43] or does not change it [44] [45] [46]. Alharbi et al. [34] observed that adding water absorbent polymers to the soil has a favorable effect on soil bulk density. Ni et al. [29] showed that round gravel mulching does not affect soil bulk density.

Data normality for water use efficiency (WUE) was confirmed by all four methods. The results of showed a significant effect for mulch application $(P<0.01)$ (Table 1). Mean comparison of the effect of mulch on water use efficiency showed a significant difference with the control. The highest water use efficiency occurred in sand treatment, and the lowest was under straw mulches. The PLANTBAC and bio-hydrogel treatments did not differ significantly in terms of water use efficiency (Figure 4). Ni et al. [29] showed that mulching improved plant growth by improving water use efficiency. Some studies suggest that gravel

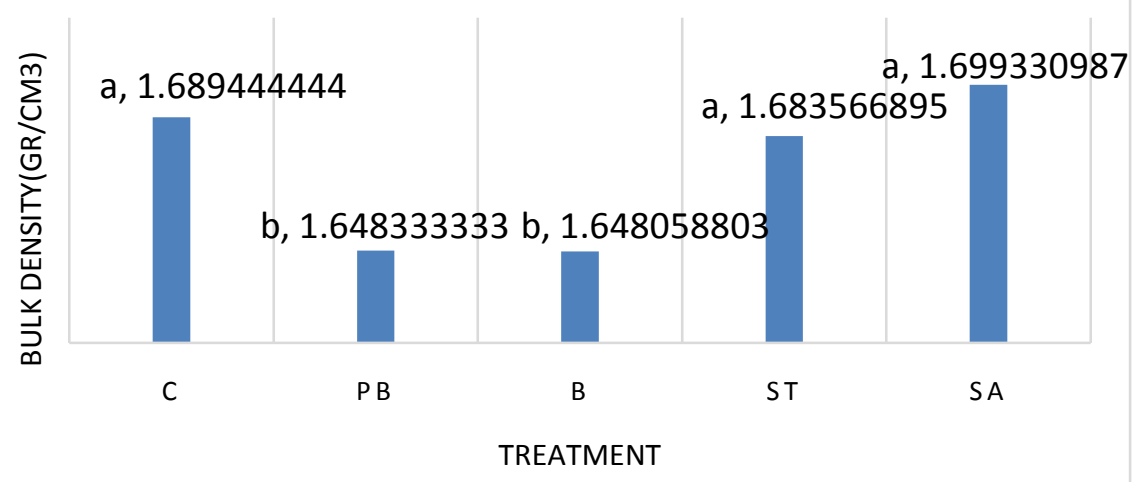

Figure 3. Effect of different treatments on bulk density. Other symbols mean biological hydrogels (b), PLANTBAC vegetation layer (pb), sand (sa) and barley straw (st). 


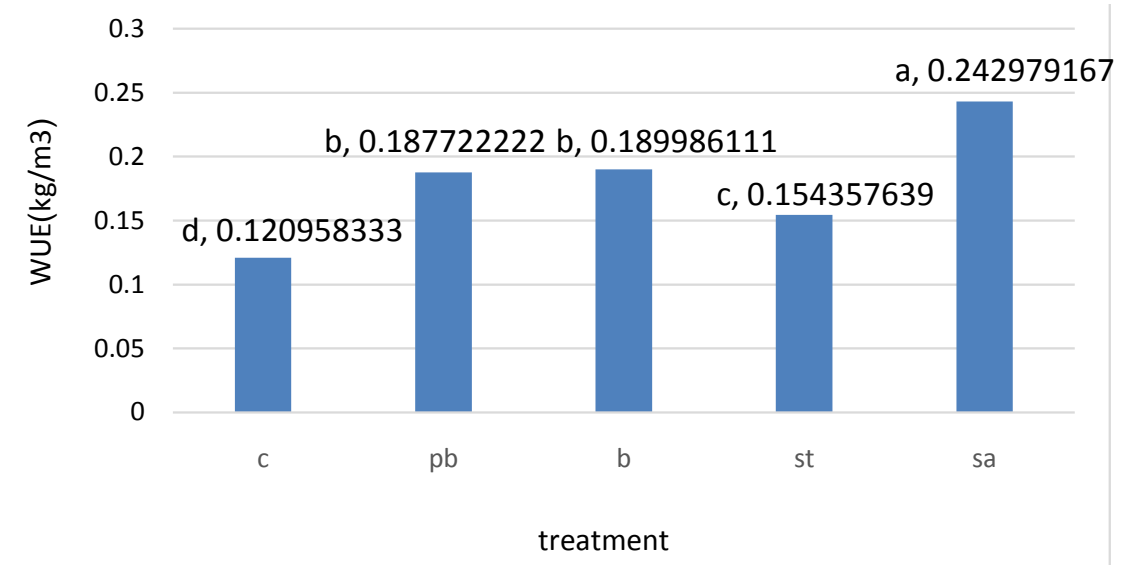

Figure 4. Effect of different treatments on water use efficiency (WUE). Other symbols mean biological hydrogels (b), PLANTBAC vegetation layer (pb), sand (sa) and barley straw (st).

mulches (Yamanaka, 2004) store water and prevent water loss through evaporation. Additionally, organic mulches conserve water more effectively than inorganic mulches [47].

Pearson correlation analysis between WUE and other properties showed a moderate negative correlation with sodium $(-0.4<\mathrm{r}<-0.6)$, a weak positive correlation with root organic matter and fresh weight of plants $(0.393$ and $0.399)$, a moderate negative correlation with electrical conductivity $(-0.396)$, a moderate positive correlation with fresh and dry weight of stem, mycorrhizal percent, dry weight of a plant, leaf area, leaf dry weight, the percentage of moisture content $(0.411,0.465,0.476,0.526,0.591,0.422,0.448$ and 0.523$)$, a strong positive correlation with plant height (0.765), a very strong positive correlation with aerial organs yield (0.883), a strong negative correlation with $\mathrm{pH}(-0.613)$ and a very strong positive correlation with dry yield of aerial organs $(0.8<\mathrm{r})$.

Sivapalan [48], reported that the amount of water retained by a sandy soil in the pressure of $0.03 \mathrm{MPa}$ increases significantly with the addition of $0.03 \%$ and $0.07 \%$ polymer to 23 and 95 percent, respectively. It was reported that with use of $0.03 \%$ and $0.07 \%$ polymer, water use efficiency for plants increases by $12 \%$ and $19 \%$, respectively. This mulch also reduces the amount of water lost by deep percolation. When the pressure rose from 0.01 to $1.5 \mathrm{MPa}$, the polymer was able to retain more water. According to Tongway and Ludwig [49], seed germination and seedling establishment improve with the technique that increases soil moisture availability [50]. In a study entitled "the effects of mulching on soil properties and runoff under semiarid conditions in southern Spain" it was concluded that mulch compensates for moisture uneven distribution, controls raindrops energy, delays runoff and increases infiltration of rainwater during storms. Yasuda et al. [51] investigated the effect of zeolite on erosion and salinity control. In this study, zeolite increased soil water holding capacity and it was introduced as a tool to reduce the effect of salinity on plants irrigated with saline water.

According to Yang et al. [32] concluded that the super absorbent polymer is 
very effective in water storage and plant establishment. Ghayor [52], in a study using $5 \mathrm{gr} / \mathrm{l}$ superabsorbent and different irrigation intervals in a Haloxylon plantation, concluded that the superabsorbent enables delaying irrigation times due to its water holding capacity and improves seedlings survival and establishment. The results of Jimenez et al. [53] on impacts of sand mulch on soil and water conservation in arid region of Lanzarote in Spain showed a 76\% reduction in water loss through evaporation. Haishenet et al. [41] in a research entitled the effect of sand-gravel mulch on soil moisture and temperature in the loess semi-arid North-West China showed that mulching has a positive impact on soil water holding capacity $(3.8 \mathrm{~cm}$ against $1.9 \mathrm{~cm}$ in the control) and temperature $\left(10.8^{\circ} \mathrm{C}\right.$ against $6.2^{\circ} \mathrm{C}$ in the control). Also, mulching reduced evaporation and enhanced water penetration. Norafkan [54] argued that the addition of amending materials to the soil increases water use efficiency and improves soil physical properties. In astudy of Yüksek and Yüksek [55], field capacity, permanent wilting point, plant available water and saturated hydraulic conductivity improved significantly due to the application of mulch. Li et al. [56] demonstrated that mulch can control soil erosion and capture wind sediments, which could reduce air pollution. Mulch can also reduce erosion by reducing surface runoff. Many studies have shown that gravel mulch reduce evaporation and runoff and effectively improves soil permeability and fertility.

About Percentage of plant establishment data normality for bulk density was confirmed by all four methods. The results of analysis of variance showed that the effects of environment, mulch and mulch environment were significant $(P<$ 0.05 ) (Table 1). The results of the mean comparison showed that the highest amount of establishment was found in microcatchment environments and straw treatment. Also, in microcatchment, the level of establishment in the three treatments of PLANTBAC, sand and hydrogel had a significant difference with the control (Figure 5).

Pearson correlation analysis showed that the percentage of plant establishment with the other characteristics measured in soil and plant showed that the percentage of plant establishment with $\mathrm{EC}$ and $\mathrm{pH}$ had a moderate negative correlation

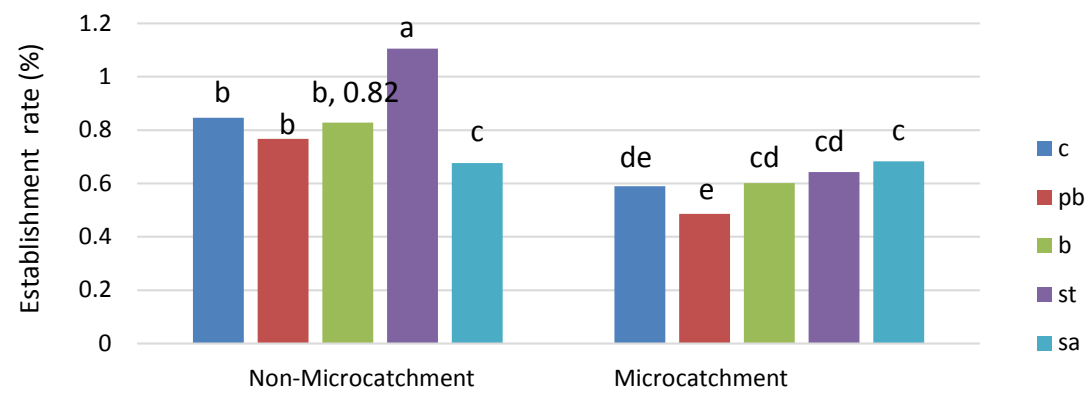

EEnvironment

Figure 5. The effect of different environment and treatments on the establishment percentage. Other symbols mean biological hydrogels (b), PLANTBAC vegetation layer (pb), sand (sa) and barley straw (st). 
(0.514 and 0.415$)$ with water use efficiency, plant weight dry and moisture content have a positive average correlation $(0.406,0.448$ and 0.459$)$. Erikiriza et al. [57] showed that plant establishment is affected in comparison with the control, which has a positive effect. It is due to the increased water holding capacity in the soil, which is consistent with the results of the present study. Establishment of perennial vegetation is very important in order to increase the accumulation of soil organic matter, since it increases the availability of nutrients and water penetration and decreases soil erosion and desertification. Restoration of lands with perennial vegetation can reduce the invasion or reestablishment of annual weeds. In particular, planting is valuable in the restoration of dry land, because shrubs, as a facilitator, reduce plant stress and provide positive feedback for the establishment of perennial vegetation [58].

\section{Conclusion}

In this study, the greatest amount of $\mathrm{Cl}^{-}$occurred in straw and sand treatments in the non-micro-catchment environment and PLANTBAC and straw treatments in the micro-catchment environment. Hence, PLANTBAC and straw mulches are recommended for the soils with low $\mathrm{Cl}^{-}$levels. The highest $\mathrm{Zn}$ values found in the straw treatments in non-micro-catchment environment; but in the micro-catchment, all treatments showed no significant difference from the control. As a result, the micro-catchment and non-micro-catchment environment has no significant impact on the amount of $\mathrm{Zn}$. The treatments had no significant impact on Fe. However, the highest amount of Fe was obtained in PLANTBAC treatment. The greatest amount of total $\mathrm{N}$ was observed in micro-catchment environment under hydrogel treatment. Also in non-micro-catchment environment, total $\mathrm{N}$ was significantly higher in hydrogel, PLANTBAC and straw treatments in comparison with the control. Hydrogel treatment had a major impact on non-micro-catchment and micro-catchment environments. Also, there was no significant difference among the environments and different treatments in terms of the amount of clay, silt and sand, reflecting the fact that mulch cannot change the texture of the soil in the short term. The PLANTBAC and bio-hydrogel treatments had significantly lower bulk density values than the control; indicating more available pores for air, water infiltration and root penetration. The treatments of sand and straw were not significantly different from the control. All treatments had significant differences with the control regarding water use efficiency. About Plant establishment, the highest amount of establishment was found in micro-catchment environments and straw treatment. Also, in micro-catchment, the level of establishment in the three treatments of PLANTBAC, sand and hydrogel had a significant difference with the control improving water use efficiency under mulch application is indicative of improvements in moisture availability and seedlings establishment in desert areas. The best water use efficiency was observed in the sand treatment, and the lowest level was under straw treatment. PLANTBAC and bio-hydrogel treatments were not significantly 
different in terms of water use efficiency. This study concludes that mulches and hydrogels are effective for soil moisture preservation and their effects on other soil and plants factors in harsh arid and desert areas, but it should be considered their prices and availability for using them.

\section{Acknowledgements}

We hereby thank all the people who helped us to do this research.

\section{References}

[1] Kianian, M.K. (2015) Review the Use of Traditional Methods of Harvesting Rainwater in Iran with the Aim of Sustainable Development: Ab-Anbar. International Conference on Sustainable Development, Strategies and Challenges, Tabriz University, Tabriz, 24-26 February 2015, 14.

[2] Hakimzadeh Ardakani, M.A., Hakimi, M.H. and Sodaeizadeh, H. (2016) Effects of Seed Source and Soil Texture on Germination and Survival of Nepeta asterotricha as a Medicinal Plant. Journal of Rangeland Science, 6, 242-252.

[3] Wang, X., Jia, Z. and Liang, L. (2014) Effect of Straw Incorporation on Soil Moisture, Evapotranspiration, and Rainfall-Use Efficiency of Maize under Dryland Farming. Journal of Soil and Water Conservation, 69, 449-455.

https://doi.org/10.2489/jswc.69.5.449

[4] Kabiri, K., Faraji-Dana, S. and Zohuriaan-Mehr, M.J. (2005) Novel Sulfobetaine-Sulfonic Acid-Contained Super Swelling Hydrogels. Polymers for Advanced Technologies, 16, 659-666. https://doi.org/10.1002/pat.637

[5] Azimi, R., Heshmati, G.A., Kianian, M.K. and Jafari, H.S. (2016) Investigating the Germination Characteristics of Poterium sanguisorba Seeds under the Influence of Thermal Treatments for Pasture Establishment. Journal of Rangeland Science, 6, 53-61.

[6] Ahmad, M., Rajapaksha, A.U., Lim, J.E., Zhang, M., Bolan, N., Mohan, D., Vithanage, M., Lee, S.S. and Ok. Y.S. (2014) Biochar as a Sorbent for Contaminant Management in Soil and Water: A Review. Chemosphere, 99, 19-33. https://doi.org/10.1016/j.chemosphere.2013.10.071

[7] Cordeiro, F.C., Santa-Catarina, C., Silveira, V. and de Souza, S.R. (2011) Humic Acids Effects on Catalase Activity and the Generation of Reactive Oxygen Species in Corn (Zea Mays). Bioscience, Biotechnology, and Biochemistry, 75, 70-74. https://doi.org/10.1271/bbb.100553

[8] Szczerski, C., Naguit, C., Markham, J., Goh, T.B. and Renault, S. (2013) Short- and Long-Term Effects of Modified Humic Substances on Soil Evolution and Plant Growth in Gold Mine Tailings. Water, Air, \& Soil Pollution, 224, 1471. https://doi.org/10.1007/s11270-013-1471-y

[9] Rees, H.W., Chow, T.L., Loro, P.J., Lavoise, J., Monteith, J.O. and Blaauw, D. (2002) Hay Mulching to Reduce Runoff and Soil Loss under Intensive Potato Production in Northwestern New Brunswick, Canada. Canadian Journal of Soil Science, 82, 249-258. https://doi.org/10.4141/S01-055

[10] Blavet, D., De Noni, G., Le Bissonnais, Y., Leonard, M., Maillo, L., Laurent, J.Y., Asseline, J., Leprun, J.C., Arshad, M.A. and Roose, E. (2009) Effect of Land Use and Management on the Early Stages of Soil Water Erosion in French Mediterranean Vineyards. Soil \& Tillage Research, 106, 124-136.

https://doi.org/10.1016/j.still.2009.04.010 
[11] Mulumba, L.N. and Lal, R. (2008) Mulching Effects on Selected Soil Physical Properties. Soil \& Tillage Research, 98, 106-111. https://doi.org/10.1016/j.still.2007.10.011

[12] Wood, M.K. and Buchanan, B.A. (2000) Reclamation Considerations for Arid Regions of the Southwest Receiving Less than $25 \mathrm{~cm}$ Annual Precipitation.

[13] Chazan, D. and Cotter, A.A. (2001) Evaluating the Impacts of Proposed Land Conversion: A Tool for Local Decision-Making, Center for Sustainable Systems. University of Michigan, Report No. CSS01-02.

[14] Chambers, J.C. (2000) Seed Movements and Seedling Fates in Disturbed Sagebrush Steppe Ecosystems: Implications for Restoration. Ecological Applications, 10, 1400-1413. https://doi.org/10.1890/1051-0761(2000)010[1400:SMASFI]2.0.CO;2

[15] Ghosh, P.K., Dayal, D., Bandyopadhyay, K.K. and Mohanty, K. (2006) Evaluation of Straw and Polythene Mulch for Enhancing Productivity of Irrigated Summer Groundnut. Field Crops Research, 99, 76-86.

[16] Li, X.Y. and Liu, L.Y. (2003) Effect of Gravel Mulch on Aeolian Dust Accumulation in the Semiarid Region of Northwest China. Soil \& Tillage Research, 70, 73-81.

[17] Hongyong, S., Liwei, S., Xiuwei, L., Wenfang, M., Suying, C. and Xiying, Z. (2012) Determination of Water Consumption and the Water-Saving Potential of Three Mulching Methods in a Jujube Orchard. European Journal of Agronomy, 43, 87-95. https://doi.org/10.1016/j.eja.2012.05.007

[18] Zhao, Y., Pang, H., Wang, J., Huo, L. and Li, Y. (2014) Effects of Straw Mulch and Buried Straw on Soil Moisture and Salinity in Relation to Sunflower Growth and Yield. Field Crops Research, 161, 16-25.

[19] Kaltenleithner, M., Strohmeier, S., Demelash, N., Ziadat, F. and Klik, A. (2014) Investigation of the Impact of Stone Bunds on Soil Water Content: A Case Study in the Northern Ethiopian Highland. Geophysical Research Abstracts, 16, 2014-3915.

[20] Bakass, M., Mokhlisse, A. and Lallemant, M. (2002) Absorption and Desorption of Liquid Water by a Superabsorbent Polymer: Effect of Polymer in the Drying of the Soil and the Quality of Certain Plants. Journal of Applied Polymer Science, 83, 234-243. https://doi.org/10.1002/app.2239

[21] García-Torres, L., Benites, J. and Martínez-Vilela, A. (2001) Conservation Agriculture, a Worldwide Challenge. Proceedings 1st World Congress on Conservation Agriculture, Madrid, 1-5 October 2001, 1-5.

[22] FAO (2003) Training Course on Water Harvesting for Improved Agricultural Production. FAO, Rome.

[23] Oweis, T., Prinz, D. and Hachum, A. (2001) Water Harvesting: Indigenous Knowledge for the Future of the Drier Environments. ICARDA, Aleppo, 40 p.

[24] Sheikh, V.B. (2014) Pamphlet of Management and Exploitation of Unconventional Waters. Faculty of Natural Resources, Gorgan University, Gorgan.

[25] Rezaee, S. (2009) Comparison of the Effects of Poly-Lattice Polymer and Oil Mulch on Seed Germination and Plant Establishment to Stabilize Dunes. Journal of Scientific-Research Range and Desert Research of Iran, 16, 136-124.

[26] Blake, G.R. and Hartge, K.H. (1986) Bulk Density. In: Klute, A., Ed., Methods of Soil Analysis, Part 1 Physical and Mineralogical Methods, 2nd Edition, Agronomy Monograph 9, American Society of Agronomy-Soil Science Society of America, Madison, 363-382.

[27] Yong, Y., Li, J., Shao, J., Deng, S., Wang, R., Li, N., Sun, J., Zhang, H., Zhu, H., Zhang, Y., Zheng, X., Zhou, D., Huttermann, A. and Chen, Sh. (2010) Effects of 
Stockosorb and Luquasorb Polymers on Salt and Drought Tolerance of Populuspopularis. Scientia Horticulturae, 124, 268-273.

[28] Aragüés, R., Teresa Medina, E. and Clavería, I. (2014) Effectiveness of Inorganic and Organic Mulching for Soil Salinity and Sodicity Control in a Grapevine Orchard Drip-Irrigated with Moderately Saline Waters. Spanish Journal of Agricultural Research, 12, 501-508. https://doi.org/10.5424/sjar/2014122-5466

[29] Ni, X., Song, W., Zhang, H., Yang, X. and Wang, L. (2016) Effects of Mulching on Soil Properties and Growth of Tea Olive (Osmanthus fragrans). PLoS ONE, 11, e0158228.

[30] Chalker-Scott, L. (2007) Impact of Mulches on Landscape Plants and the Environment. A Review. Journal of Environmental Horticulture, 25, 239-249.

[31] Brown, M.F. and Whitford, W.G. (2003) The Effects of Termites and Straw Mulch on Soil Nitrogen in a Creosotebush (Larrea tridentata) Dominated Chihuahuan Desert Ecosystem. Journal of Arid Environments, 53, 15-20.

[32] Yang, L., Yang, Y., Chen, Z., Guo, C. and Li, S. (2014) Influence of Super Absorbent Polymer on Soil Water Retention, Seed Germination and Plant Survival for Rocky Slopes Eco-Engineering. Ecological Engineering, 62, 27-32. https://doi.org/10.1016/j.ecoleng.2013.10.019

[33] Li, X.Y., Liu, L.Y. and Gong, J.D. (2001b) Influence of Pebble Mulch on Soil Erosion by Wind and Trapping Capacity for Windblown Sediment. Soil \& Tillage Research, 59, 137-142.

[34] Alharbi, A. (2015) Effect of Mulch on Soil Properties under Organic Farming Conditions in Center of Saudi Arabia. Journal of American Science, 11, 20-32.

[35] Tisdale, S.L., Nelson, W.L., Beaton, J.D. and Havlin, J.L. (1993) Soil Fertility and Fertilizers. MacMillan, New York, 634.

[36] Watt, D.B., Torbert, H.A., Prior, S.A. and Huluka, G. (2010) Long-Term Tillage and Poultry Litter Impacts Soil Carbon and Nitrogen Mineralization and Fertility. Soil Science Society of America Journal, 74, 1239-1247. https://doi.org/10.2136/sssaj2008.0415

[37] Engel, H. (1934) Zur Physiologieder Nitrifikationsorganismen in natürlichenBöden. Zbl. Bakt. II, 90, 384.

[38] Pakdel, P., Tehranifar, A., Nemati, H., Lakzian, A. and Kharrazi, M. (2013) Effect of Different Mulching Materials on Soil Properties under Semi-Arid Conditions in Northeastern Iran. Wudpecker Journal of Agricultural Research, 2, 80-85.

[39] Qi, Y., Yang, F., Shukla, M.K., Pu, J., Chang, Q. and Chu, W. (2015) Desert Soil Properties after Thirty Years of Vegetation Restoration in Northern Shaanxi Province of China. Arid Land Research and Management, 29, 454-472.

[40] Noy-Meir, I. (1973) Desert Ecosystems: Environment and Producers. Annual Review of Ecology and Systematics, 4, 25-51.

[41] Haishen, L., Yonghua, Z., Zhongbi, Y. and Long, X. (2009) Proc. of JS. 1 at the Joint IAHS \& IAH Convention, Hyderabad, India. IAHS Publ. 328.

[42] Ji, S. and Unger, P.W. (2001) Soil Water Accumulation under Different Precipitation, Potential Evaporation, and Straw Mulch Conditions. Soil Science Society of America Journal, 65, 442-448.

[43] Bottenberg, H., Masiunas, J., Eastman, C. and Eastburn, D.M. (1997) The Impact of Rye Cover Crops on Weeds, Insects, and Diseases in Snap Bean Cropping Systems. Journal of Sustainable Agriculture, 9, 131-155. 
[44] Blevin, R.L., Smith, M.S., Thomas, G.W. and Frye, W.W. (1983) Influence of Conservation Tillage on Soil Properties. Journal of Soil and Water Conservation, 38, 301-305.

[45] Acosta, M.V., Reicher, Z., Bischoff, M. and Turco, R.F. (1999) The Role of Tree Leaf Mulch and Nitrogen Fertilizer on Turfgrass Soil Quality. Biology and Fertility of Soils, 29, 55-61.

[46] Duiker, S.W. and Lal, R. (1999) Crop Residue and Tillage Effects on Carbon Sequestration in a Luvisol in Central Ohio. Soil \& Tillage Research, 52, 73-81.

[47] Singh, B., Gupta, G.N., Prasad, K.G. and Mohan, S. (1988) Use of Mulches in Establishment and Growth of Tree Species on Dry Lands. Indian Forester, 114, 307-316.

[48] Sivapalan, S. (2001) Effect of Polymer on Soil Water Holding Capacity and Plant Water Use Efficiency. Proceedings 10 th Australian Agronomy Conference, Hobart, Tasmania, Australia.

[49] Tongway, D.J. and Ludwig, J.A. (1996) Rehabilitation of Semiarid Landscapes in Australia. 1. Restoring Productive Soil Patches. Restoration Ecology, 4, 388-397.

[50] Jordán, A., Zavala, L.M. and Gil, J. (2010) Effects of Mulching on Soil Physical Properties and Runoff under Semi-Arid Conditions in Southern Spain. Catena, 81, 77-85. https://doi.org/10.1016/j.catena.2010.01.007

[51] Yasuda, H., Takuma, K., Fukuda, T., Araki, Y., Suzuka, J. and Fuku Yongma, Y. (1998) Effect of Zeolite on Water and Salt Control in Soil. Tottori Daigaku Nogakubu Kenkyu Hokoku, 51, 35-42.

[52] Ghayor, F. (2004) Measuring the Effectiveness of Two Types of Absorbent Polymer to Increase Water Productivity in Desertification Projects. Final Report of Research Project, Center of Agriculture and Natural Resources of Isfahan. Evaporation, and Straw Mulch Conditions. Soil Science Society of America Journal, 65, 442-448.

[53] Jiménez, M.N., Pinto, J.R., Ripoll, M.A., Sánchez-Miranda, A. and Navarro, F.B. (2017) Impact of Straw and Rock-Fragment Mulches on Soil Moisture and Early Growth of Holm Oaks in a Semiarid Area. Catena, 152, 198-206.

[54] Norafkan, H. (2007) Benefits of Stockosorb and Zeolite in Greenhouses Soils. The First Technical Workshops to Improve Water Use Efficiency by Greenhouse Crops, No. 18.

[55] Yüksek, T. and Yüksek, F. (2011) The Effects of Restoration on Soil Properties in Degraded Land in the Semi-Arid Region of Turkey. Catena, 84, 47-53.

[56] Li, X.Y., Gong, J.D., Gao, Q.Z. and Li, F.R. (2001) Incorporation of Ridge and Furrow Method of Rainfall Harvesting with Mulching for Crop Production under Semi-Arid Conditions. Agricultural Water Management, 50, 173-183.

[57] Orikiriza, L.J.B., Agaba, H., Tweheyo, M., Eilu, G., Kabasa, J.D. and Hüttermann, A. (2009) Amending Soils with Hydrogels Increases the Biomass of Nine Tree Species under Non-Water Stress Conditions. Clean, 37, 615-620.

[58] Castro, J.J., Santiago, J.A. and Santana-Ortega, A.T. (2002) A General Theory on Fish Aggregation to Floating Object: An Alternative to the Meeting Point Hypothesis. Reviews in Fish Biology and Fisheries, 11, 255-277. 